a combination of e.g. animations, videos with personal patient stories, podcasts, written text, spoken words and interactive quizzes.

Conclusion: The e-learning program is developed and ready for feasibility testing. Subsequently, the effectiveness of the program will be tested in a RCT study among approximately 250 patients.

References:

[1] Zangi HA, Ndosi M, Adams J, et al. EULAR recommendations for patient education for people with inflammatory arthritis. Ann Rheum Dis. 2015; 0:1-9.

[2] Braun V, Clarke V. Using thematic analysis in psychology. Qualitative research in psychology. 2006; 3 (2): 77-101.

[3] Mayer R. The Cambridge handbook of multimedia learning. 2005. New York.

[4] Singhal A, Cody MJ, Rogers EM, Sabido M (editors). Entertainment-education and social change - History, research and practice. Taylor and Francis; 2003.

Acknowledgments: We thank the participants in focus groups who shared their experiences. We also express our gratitude to the Novo Nordisk Foundation for supporting the study. Furthermore, we are grateful for the collaboration with the communication consultants, graphic designers and the e-learning company, who have contributed to the development of the e-learning platform.

Disclosure of Interests: Line Raunsbæk Knudsen Consultant of: Phizer (Not relevant for the present study)., Speakers bureau: Phizer (Not relevant for the present study).

Lily (Not relevant for the present study).

Roche (Not relevant for the present study)., Kirsten Lomborg: None declared Annette de Thurah Grant/research support from: Novartis (not relevant for the present study)., Speakers bureau: Lily (not relevant for the present study). DOI: 10.1136/annrheumdis-2020-eular.2280

\section{AB1309-HPR EFFICACY OF ADDING CAFFEINE TO THE TREATMENT REGIMEN IN REDUCING METHOTREXATE INTOLERANCE IN PATIENTS WITH RHEUMATOID ARTHRITIS: A RANDOMIZED CONTROLLED STUDY}

A. Fehr ${ }^{1}$, F. El Noby ${ }^{2}$, N. Fathi ${ }^{3}$, R. Lotfy ${ }^{2} .{ }^{1}$ Faculty of Medicine, Helwan University, Rheumatology \& Physical Medicine Department, Helwan, Egypt; ${ }^{2}$ Faculty of Medicine, Aswan University, Rheumatology Department, Aswan, Egypt; ${ }^{3}$ Assuit Faculty of Medicine, Assuit, Egypt

Background: Rheumatoid arthritis is one of common form of chronic inflammatory arthritis. Methotrexate has remained anchor treatment because of its potent efficacy ${ }^{1}$. Intolerance to Methotrexate is a common cause of non-compliance ${ }^{2 \& 3}$. Objectives: To investigate the effect of adding caffeine orally as Methylxanthines (Caffeine), act as adenosine receptor antagonists ${ }^{4}$ to reduce symptoms of moderate to severe methotrexate intolerance in patients with Rheumatoid Arthritis ${ }^{5}$. Methods: A prospective, randomized controlled study conducted at Aswan University Hospital, Egypt from Jan 2018 till may 2019. Sixty patients with Rheumatoid arthritis who have had experienced moderate to severe methotrexate intolerance was enrolled in the study. The methotrexate intolerance severity score (MISS) ${ }^{6}$ was evaluated at base line before initiation of study then at the next three months consecutively. Patients were randomly assigned by closed envelope method into 2 groups each containing 30 patients: Group (A); 30 patients was prescribed caffeine (coffee or dark chocolate) as an antidote to methotrexate intolerance $^{7}$. Group (B); 30 matched patients acted as control group that included who will continue methotrexate regimen without addition of any extra caffeine.

Results: Twenty four patients $(80 \%)$ at time three follow up visit showed full improvement of symptoms of methotrexate-intolerance compared to ten patients (33.3\%) at 2nd month follow up visit and seven patients (23\%) at 1st month follow up visit with statistically significant difference all over the study period $(\mathrm{P}=0.005)$. half of study group patients discontinued anti-emetic and other drugs while none in control group did.

Conclusion: Adding caffeine to management regimen can reduce the symptoms of severe methotrexate-intolerance in Rheumatoid Arthritis patients.

References:

[1] Friedman, B., \& Cronstein, B. (2019). Methotrexate Mechanism in Treatment of Rheumatoid Arthritis. Joint Bone Spine, 86(3):301-307

[2] Wang, W., Zhou, H., \& Liu, L. (2018). Side effects of methotrexate therapy for rheumatoid arthritis: a systematic review. European journal of medicinal chemistry. Volume 158, 502-516

[3] Bulatović, M., Heijstek, M. W., Verkaaik, M., van Dijkhuizen, E. P., Armbrust, W., Hoppenreijs, E. P., ... \& Rademaker, C. M. (2011). High prevalence of methotrexate intolerance in juvenile idiopathic arthritis: development and validation of a methotrexate intolerance severity score. Arthritis \& Rheumatism, 63(7), 2007-2013.

[4] Malaviya, A., Baghel, S., Verma, S., Thakran, R., \& Messi, C. (2019). Use of coffee for alleviating methotrexate intolerance in rheumatic diseases. Indian Journal of Rheumatology, 14(1), 79-79.

[5] Ribeiro, J. A., \& Sebastiao, A. M. (2010). Caffeine and adenosine. Journal of Alzheimer's Disease, 20(s1), S3-S15.

[6] Fatimah, N., Salim, B., Nasim, A., Hussain, K., Gul, H., \& Niazi, S. (2016). Frequency of methotrexate intolerance in rheumatoid arthritis patients using methotrexate intolerance severity score (MISS questionnaire). Clinical rheumatology, 35(5), 1341-1345.

[7] Malaviya, A. N. (2017). Methotrexate intolerance in the treatment of rheumatoid arthritis (RA): effect of adding caffeine to the management regimen. Clinical rheumatology, 36(2), 279-285.

Disclosure of Interests: None declared

DOI: 10.1136/annrheumdis-2020-eular.1887

\section{AB1310-HPR EFFECTS OF INSTRUMENT-ASSISTED SOFT TISSUE MOBILIZATION ON FROZEN SHOULDER: A RANDOMIZED CONTROLLED TRIAL}

E. Kaya Mutlu ${ }^{1}$, T. Birinci ${ }^{2}$, S. Kılıc ${ }^{3} .{ }^{1}$ Istanbul University-Cerrahpasa, Department of Physiotherapy and Rehabilitation, Istanbul, Turkey; ${ }^{2}$ Istanbul Medeniyet University, Department of Physiotherapy and Rehabilitation, Istanbul, Turkey; ${ }^{3}$ Istanbul Aydın University, Institute of Health Sciences, Istanbul, Turkey

Background: Frozen shoulder has a greater incidence, more severe course, and resistance to treatment in patients. Management is based on the underlying cause of pain and stiffness. Joint mobilization has been reported to improve joint range of motion in frozen shoulder. However, there is no information regarding the effect of instrument-assisted soft tissue mobilization (IASTM) in frozen shoulder. We proposed that there would be no significant difference between the two manual physical therapy techniques with relatively similar treatment effects in the frozen shoulder.

Objectives: The aim of this randomized controlled study was to compare the effectiveness of IASTM and joint mobilization in the treatment of patients with frozen shoulder.

Methods: Thirty patients with phase II frozen shoulder (mean age 50,9 years, age range 39-65 years) were randomly assigned to one of the two treatment groups: Group I received joint mobilization combined with manual stretching exercise and Group II received IASTM with manual stretching exercise (two days per week for six weeks) (Figure 1). The pain level was evaluated with a visual analogue scale (VAS) and the active range of motion (ROM) was measured with a universal goniometer. The Disabilities of the Arm, Shoulder and Hand score and the Constant-Murley score were used for functional assessment. The assessments were performed at baseline and after the 6-week intervention.

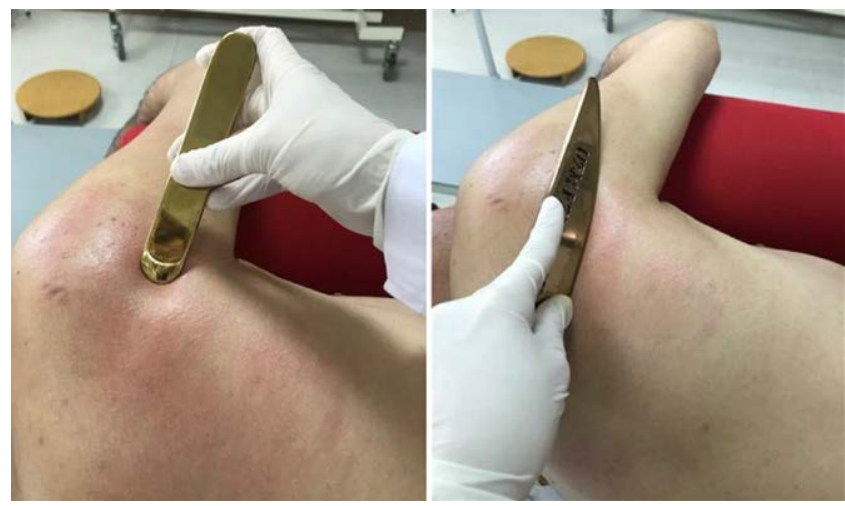

Figure 1. Instrument-Assisted Soft Tissue Mobilization

Results: Both groups had a significant decrease in pain according to VAS and a significant increase in ROM and function level $(p<0.05)$. After the 6-week intervention, improvement of shoulder abduction ROM in Group I was found significantly higher than Group II ( $p=0.01)$, on the other hand, Constant-Murley score in Group II was found significantly higher compared to Group I ( $p=0,001)$.

Conclusion: Our results supported the hypothesis that either joint mobilization or IASTM, performed in addition to stretching exercise, provided similar improvements in pain levels in patients with the frozen shoulder.

References:

[1] Kelley MJ, Shaffer MA, Kuhn JE, Michener LA, Seitz AL, Uhl TL, et al. Shoulder Pain and Mobility Deficits: Adhesive Capsulitis, J Orthop Sports Phys Ther, 2013:43:1-31.

[2] Celik D, Kaya Mutlu E. Does Adding Mobilization to Stretching Improve Outcomes for People with Frozen Shoulder? A Randomized Controlled Clinical Trial, Clin Rehab, 2016: 30(8): 786-794.

[3] Iked N, Otsuka S, Kawanishi Y, Kawakami Y. Effects of Instrument-Assisted Soft Tissue Mobilization on Musculoskeletal Properties, Med Sci Sports Exerc, 2019:51(10): 2166-2172.

Disclosure of Interests: None declared

DOI: 10.1136/annrheumdis-2020-eular.6151 